\title{
Economic Analysis of Woody Biomass Supply Chain in Maine
}

Stephanie Whalley ${ }^{\mathrm{a}^{*}}$, Sharon JW Klein ${ }^{\mathrm{a}}$, Jeffrey Benjamin ${ }^{\mathrm{b}}$

${ }^{a}$ School of Economics, University of Maine, 5782 Winslow Hall, Rm 206, Orono, ME, USA

04469-5782; phone: 1-207-581-3174; fax: 1-207-581-4278; email:

stephaniemwhalley@gmail.com, sharon.klein@maine.edu

${ }^{\mathrm{b}} \mathrm{School}$ of Forest Resources, University of Maine, 247 Nutting Hall Orono, ME, USA 04469-

5755; 1-207-581-2727; jeffrey.g.benjamin@ maine.edu

*Corresponding author

\begin{abstract}
An economic biomass supply chain model for Maine was developed to estimate the delivered cost of biomass chips using the stumpage price paid to the landowner, the cost of harvesting and chipping the logging residues, and the cost of transporting the biomass chips to a biorefinery for biofuel production. Harvesting costs were estimated using Maine-specific productivity equations, harvesting assumptions, and hourly costs, but the resulting model is applicable to any region with woody biomass. Transportation costs were estimated using round trip distance to the potential biorefinery. The delivered cost of biomass was estimated for multiple scenarios, including different machine cost rates, variables impacting machine productivity, transport distance, and stand characteristics. When biomass was treated as a waste product (only chipping costs included), the estimated delivered biomass cost was $\$ 11 /$ green tonne (GT) (with a sensitivity analysis range of $\$ 4$ to $\$ 24 / \mathrm{GT}$ ), less than half the current biomass chip price in Maine (\$28/GT). When a portion of the harvesting cost was included in the
\end{abstract}


delivered biomass cost, the estimated delivered biomass cost increased three-fold to $\$ 30 / \mathrm{GT}$ (with a range of $\$ 8-\$ 82 / G T$ ). The results of this analysis will serve as a portion of an integrated sustainability assessment for a new biofuel pathway. This model can be easily adapted to other geographical regions with different site-specific inputs.

\section{Keywords}

Woody biomass, biomass cost, Maine, biofuel, supply chain

\section{Introduction}

As the US seeks to decrease reliance on fossil fuels by increasing the use of renewable energy, woody biomass (tree tops and branches - also called energy wood and harvest or logging residues) has received increased attention as a possible renewable feedstock for electricity generation, heating, and transportation fuels. The expanded US Renewable Fuel Standard (RFS2) sets annual volume requirements for biofuel production, which increase annually and gradually include larger percentage standards for advanced biofuels (anything other than corn starch ethanol) [1]. As over $80 \%$ of Maine is forested, the highest proportion of any state in the US, Maine is a strong candidate for producing biofuel from logging residues [2]. Additionally, Maine has an active biomass chip market, in which the tree tops and limbs are chipped and sold to generate heat or electricity, providing approximately $15 \%$ of total energy for the state [3]. However, in many cases all of the biomass is still left on site. Woody biomass from Maine is of particular interest for producing environmentally sustainable biofuels because nearly all of the harvested forests are naturally regenerated; clear-cutting is rare; and biomass is typically underutilized. Unlike some biofuel feedstocks, woody biomass does not conflict with food production or require inputs such as fertilizer, insecticides, or pesticides [4] (which could harm 
wildlife and water quality). Forests are also able to maintain species diversity better than monocrops [5].

The University of Maine Forest Bioproducts Research Institute (FBRI) has developed a new production pathway that converts wood derived cellulose into a drop-in biofuel using thermal deoxygenation (TDO), which can be used to produce biofuel from logging residues [6]. The overall goal of this study is to estimate the cost of purchasing the biomass chips within the area surrounding a potential TDO biorefinery in Old Town, Maine. An economic biomass supply chain model was created to accomplish this goal. This model can be adapted for a variety of geographic regions, by replacing Maine-specific parameters and equations with site-specific information from other regions.

\subsection{Maine Biomass Supply Chain}

The biomass supply chain in Maine is integrated with conventional roundwood harvesting and involves many different landowners (98\% of forestland is owned privately [2]), logging and trucking contractors, and end users. In some cases, the landowner sells trees and timber products to a logging contractor for a stumpage price prior to harvest. It is also common for landowners to pay loggers contract prices for harvest and transport. Then the landowner markets the wood products separately. Either way all parties must be compensated out of the mill delivered price. We chose to model the process using publicly available stumpage prices [7], which approximate the contracted harvesting price, as similar costs would need to be covered. The logging contractor then harvests the trees and removes the tree tops and branches (biomass) from the bole [8]. Biomass is usually transported to a roadside landing during or after harvest and chipped to increase load density for transport. Trucks transport the biomass chips to a purchasing facility. The final cost of the delivered biomass chips to the purchasing facility 
includes stumpage, harvesting, chipping, logging contractor profit margin, and trucking costs (Figure 1.1).

Biomass is chipped in conjunction with timber harvesting as part of an integrated harvesting operation. Three different harvesting methods are commonly used in Maine: whole tree (WT), cut-to-length (CTL), and tree length (TL). Each method varies in cost, amount of biomass harvested, environmental impact, and the type of machines used. Our biomass supply chain model assumes a WT harvest method because $82 \%$ of Maine forest products by volume are harvested using the WT method [9] and because a greater proportion of biomass is recovered with WT than with other harvesting methods as the entire tree is transported to the roadside landing. The typical WT method in the Northeast uses a feller-buncher to cut down the tree, a grapple skidder to drag a bunch of trees to the roadside landing, and a stroke delimber to remove the biomass at the landing. At least a portion of the biomass is placed on trails to reduce erosion and soil compaction in accordance with Maine Forest Service (MFS) water quality best management practices [10].

Trucks transport biomass chips directly from forest to end-user. While data are not available for Maine, the average forest product trucking distance in neighboring states (New York, Vermont, and New Hampshire) is 74 kilometers, and approximately $75 \%$ of logging contractors in these states subcontract at least a portion of their trucking [9].

\subsection{Review of Existing Biomass Supply Chain Studies and Models}

While several studies have estimated biomass harvesting and transportation costs nationally [11,12], in the Northwest [13-15], Southeast [16-18], and in the upper Midwest $[19,20]$, few studies have addressed the Northeast [21]. In Maine, some recent studies have 
addressed individual aspects of the biomass supply chain, such as logging contractor characteristics and harvesting methods [9], harvesting productivity [22,23], early commercial thinning costs [24], and challenges for expanding biomass harvesting in Maine [25]; however, no studies have thoroughly analyzed the costs for harvesting and transporting biomass to the end user in Maine. Since harvesting practices, harvest block characteristics, and species composition vary by state, harvesting productivity, cost, stumpage prices, and transportation costs need to be analyzed at the state level to accurately estimate the feedstock cost for a potential biorefinery.

As machine productivity and cost rates are used together to estimate unit cost of production, applicable productivity equations and accurate costs that represent current machines and practices are essential for accurately estimating in-state harvesting costs. The Fuel Reduction Cost Simulator (FRCS) is a spreadsheet-based tool developed by the US Forest Service to estimate the cost of harvesting and delivering timber and woodchips to roadside for a specified area of forestland. FRCS includes three variants: West, North, and South. FRCS-North, updated in March 2010, incorporates machine specific costs, regional variations such as differences in the added cost of harvesting hardwood trees, and state specific labor costs [26]. However, it does not include productivity equations or costs specific to Maine or the Northeast [22]. FRCS-North machine cost rate (average hourly cost to own and operate a piece of equipment) calculation assumptions, including wages and benefits estimated using a wage index based on Missouri from 2000 to 2007, do not reflect current costs in Maine. There is a general lack of machine productivity estimates applicable to Maine in academic literature as well [27]. For example, most productivity studies focus on low-density stands (fewer than 100,000 trees $/ \mathrm{km}^{2}$ ), whereas Maine stands range from 100,000 to 480,000 trees $/ \mathrm{km}^{2}$ [27]. 
Additionally, many biomass cost estimates do not include all of the costs along the supply chain. Abbas et al. [28] use FRCS to estimate delivered biomass costs in Michigan at \$8$\$ 107 /$ green tonne (GT) (WT harvest, 30\% tree removal) and \$8-\$105/GT (WT harvest, 70\% tree removal), with most of the total cost attributed to harvesting (nearly 50\%) and transportation (nearly 30\%). However, they do not include profit, overhead, or management expenses in the final calculations. The US Department of Energy (DOE) and Oak Ridge National Laboratory also use FRCS in the Billion-Ton Update (BTU), which estimates sustainable annual US biomass availability and cost (at the roadside, not including transport to the end user) for biofuel production: 30-129 million dry tonnes/y nationally (at \$22-\$110/dry tonne, respectively), and 0.17-1.00 million dry tonnes/y in Maine (at \$22-\$220/dry tonne, respectively) [12]. These results are based on WT harvesting (with a minimum of $30 \%$ biomass left on site to return nutrients to the soil and reduce runoff) and only include chipping and stumpage costs (no costs associated with other harvesting machines).

While biomass may currently be a waste product of the forestry industry, resulting in many studies allocating the entire harvesting cost to timber products, this does not take into account the opportunity cost of allocating resources to harvesting biomass. Some studies in the Southeast have shown that this opportunity cost may be important $[16,17]$, and limiting biomass harvesting cost to only chipping may underestimate the total cost. Conrad et al. [16] compared the cost of WT harvesting (with different harvesting equipment than Maine) and transportation of roundwood in North Carolina under three scenarios: 1) roundwood harvesting only (no biomass chipping); 2) integrated roundwood harvesting and biomass chipping; 3) biomass chipping only (no roundwood harvesting - similar to BTU). The authors [16] found that a contractor could earn a profit of $\$ 1.52 /$ tonne for harvesting roundwood under scenario 1 and lose 
$\$ 0.28 /$ tonne under scenario 2. Conrad et al. [16] estimated that for the integrated harvesting system to reach its breakeven point, the feller-buncher would have to achieve an unrealistically high $98 \%$ utilization rate (FRCS-North assumes a utilization of 60\%). Jernigan et al. [17] also found that the opportunity cost of biomass chipping and delivery in the Southeastern US (\$1819/tonne from clearcut and thinning operations, respectively, including $\$ 2.20 /$ tonne profit but no stumpage) is large enough to prevent logging contractors from harvesting biomass at current prices.

Our biomass supply chain model advances previous research in this area by incorporating Maine-specific data and calculations with FRCS-North and comparing delivered biomass cost under two scenarios: chipping only (similar to BTU) and integrated with roundwood harvesting (proportioned harvesting costs).

\section{Material and Methods}

Our biomass supply chain model was created in the computer program " $R$ " [29] and includes calculations of minimum, maximum, and default delivered biomass costs based on input data associated with stumpage, harvesting, and trucking costs (Tables 1.1-1.2). Default values are based on potential harvesting blocks within an 80-kilometer radius of a potential biorefinery facility in Old Town, Maine. The minimum-maximum ranges reflect the input values used to calculate the minimum and maximum delivered biomass cost; in some cases the minimum input value was used to calculate the maximum delivered biomass cost and vice-versa. While these ranges in many cases are expected to be more extreme than actual conditions in Maine, they provide upper and lower bounds. For instance, diesel prices are not expected to approach $\$ 1.59$ 
per liter in the near future and while the skidding distance may be 762 meters (m) for portions of a stand, it is unlikely that the average skidding distance would be $762 \mathrm{~m}$.

The baseline forest stand data (tree volume, diameter at breast height (DBH), and hardwood fraction) are from the US Forest Service Forest Inventory and Analysis (FIA) Database for the entire 80-kilometer radius around Old Town Fuel and Fiber. The stand characteristics are varied to demonstrate changes in harvesting costs depending on specific characteristics of potential harvest blocks within the sample plot (see Supplementary Material (SM), Appendix A). We also varied the diesel fuel price, which is an input to the machine cost rate and trucking cost calculations, to analyze how increasing fuel prices impact biomass costs from harvest to delivery.

We used Maine-specific Equations 2.1-2.5, developed by Hiesl and Benjamin [22][23], to estimate the productivity of a feller buncher $\left(\mathrm{P}_{\mathrm{FB}}\right)$, grapple skidder $\left(\mathrm{P}_{\mathrm{GS}}\right)$, and stroke delimber $\left(\mathrm{P}_{\mathrm{SD}}\right) . \mathrm{P}_{\mathrm{FB}}$ requires a stem count (number of trees) per accumulation [22], which we estimated based on average DBH: 5 stems for DBH $<10 \mathrm{~cm} ; 3$ stems for $10 \mathrm{~cm}<\mathrm{DBH}<18 \mathrm{~cm} ; 1$ stem for $\mathrm{DBH}>18 \mathrm{~cm}$. The machine cycle refers to the amount of time it takes for the machine to complete a work cycle - beginning and ending with an empty accumulator in the case of the feller buncher [22]. The DBH sum per accumulation (SumDBH) was calculated by multiplying average DBH by average stem count per accumulation. Hiesl and Benjamin's [23] $\mathrm{P}_{\mathrm{GS}}$ equation is designed for estimating the cycle time per tree using a dummy variable for hardwood vs softwood; to adapt it to stand summary data, we first calculated hardwood and softwood productivity using Equation 2.3 and then used the hardwood fraction to weight the stroke delimber productivity in Equation 2.4. We used a range of 27-95 green tonnes per productive 
machine hour (PMH: the time when the machine is working). [30] for the chipper because Maine-specific chipper productivity equations have not yet been developed.

$$
\begin{aligned}
& P_{F B}=C F_{M H R} * \frac{1}{\exp (-0.888+0.136 * \text { StemCount }+0.017 * \text { SumDBH })} * V_{t} * \text { StemCount } \\
& P_{G S}=C F_{M F T 3} *\left(\exp \left(1.754-0.0005 * D_{S}+0.755 * V_{S B}\right)\right) \\
& P_{L}=\frac{170}{.66+46.2 / D B H} \\
& P_{S D, H W}=(-0.708+0.219 * D B H)^{2} ; \\
& P_{S D, S W}=(-0.058+0.219 * D B H)^{2} ; \\
& S W=\text { softwood \& } H W=\text { hardwood } \\
& P_{S D}=P_{S D, H W} * f_{H W}+P_{S D, S W} *\left(1-f_{H W}\right)
\end{aligned}
$$

We calculated hourly machine cost rates following the methodology of Brinker et al [34] (SM, Appendix B), which is also used in FRCS-North and Abbas et al. [19], using Mainespecific input data [24] for the feller buncher, grapple skidder, and stroke delimber and FRCSNorth data for the chipper and loader. In practice, machine cost rates are highly variable, depending on how well machines actually operate and how frequently repair and maintenance are required. Therefore, we calculated lower and upper bounds by varying the machine purchase price, power rating, wages and benefits, and rates of utilization, repair and maintenance, interest, insurance, tax, and fuel consumption (SM, Appendix B).

While stumpage prices are assumed to cover the expenses and profit of landowners, and the trucking cost per kilometer includes the costs and profit for trucking companies, the machine rates used to calculate harvesting costs do not include the overhead costs and profit for the logging contractors. Abbas et al. [28] excluded profit from their analysis. Jernigan et al. [17] included $\$ 2.20 /$ tonne for profit and overhead expenses for the thinning operation, which is equivalent to $12 \%$ profit. Conrad [16] estimated that the conventional roundwood harvesting (not integrated with biomass harvesting) profit was $\$ 1.52 /$ tonne and argued that biomass harvesting 
must at least equal the profit of roundwood harvesting, which would equal $6 \%$ profit. The machine rate methodology, which estimates cost per machine rather than for the operation as a whole, does not include profit or overhead expenses; therefore, we included a range for overhead and profit of $5-15 \%$ of the harvesting cost.

We used the machine productivity and machine cost rates to calculate harvest cost per unit harvested (volume for timber and mass for biomass) (Equations 2.6-2.21), based on partialcut harvesting, rather than clearcutting, because comparatively few areas are clearcut in Maine (i.e., in 2012, 95\% of the harvested area in Maine was either partially harvested or commercially thinned rather than clearcut [4]). Equations 2.6-2.10 calculate the volume and mass of the timber and biomass harvests. Not all of the logging residues can be recovered because residues are dropped during harvest and retained to meet biomass retention requirements for water quality best management practices. Equation 2.9 limits the biomass harvest using the biomass recovery fraction, which is the fraction of the total logging residues expected to be recovered when trees are harvested [26][12][24][35]. Equations 2.11 and 2.12 calculate the harvesting cost per unit volume and area, respectively, for each machine. The total harvest cost is the sum of the individual machine harvest costs (Equation 2.13). Equations 2.14 and 2.15 calculate the volume and mass, respectively, of the total harvest. Equations 2.16-2.17 calculate the timber and biomass harvest fractions for the respective equations below. Equations 2.18-2.21 calculate the biomass (and timber) harvesting cost using two different methodologies: 1) biomass cost includes a portion of the total harvesting costs based on the volume harvested (Equation 2.18-2.19, Figure 2.1 and 2.2); and 2) all harvesting costs are attributed to timber cost; biomass cost only includes chipping cost (Equation 2.20-2.21, Figure 2.2). We calculate both volume and mass because volume is commonly used when discussing timber and mass is used for biomass chips. 


$$
\begin{aligned}
& N_{t H}=N_{t} * f_{H R} \\
& V_{T H}=V_{t} *\left(1-f_{B}\right) * N_{t H} \\
& M_{T H}=\frac{V_{T H} * \rho}{C F_{K G T}} \\
& V_{B H}=f_{B} * f_{B R} * V_{t} * N_{t H,} \\
& M_{B H}=\frac{V_{B H} * \rho}{C F_{K G T}} \\
& C_{i, V}=\frac{C_{i}}{P_{i}} \\
& C_{i, A}=C_{i, V} * V_{t} * N_{t H} \\
& C_{H}=s u m\left(C_{i, A}\right) \\
& V_{H}=V_{T H}+V_{B H} \\
& M_{H}=M_{T H}+M_{B H} \\
& f_{T H}=\frac{V_{T H}}{V_{H}} \\
& f_{B H}=\frac{M_{B H}}{M_{H}} \\
& C_{T H p}=\frac{\left(C_{F B, A}+C_{G S, A}+C_{S D, A}\right) * f_{T H}+C_{L, A}}{M_{T H}} \\
& C_{B H p}=\frac{\left(C_{F B, A}+C_{G S, A}+C_{S D, A}\right) * f_{B H}+C_{C H, A}}{M_{B H}} \\
& C_{T H n p}=\frac{C_{F B, A}+C_{G S, A}+C_{S D, A}+C_{L, A}}{M_{T H}} \\
& C_{B H n p}=\frac{C_{C H, A}}{M_{B H}}
\end{aligned}
$$

Next, the cost to transport biomass chips to the end user was calculated in the biomass supply chain model. Five different companies in the Northeast with chip vans reported average loads between 25 and 30 green tonnes [36]. The one-way distance (from the harvested block to the market) can substantially increase the cost per GT, so biomass chips are usually not transported long distances. A study of wood pellet based energy sources in Maine used an average delivery distance of 161 kilometers for wood pellets, though wood prices are approximately $\$ 44 /$ tonne, at least $\$ 10$ greater than the price of biomass chips for a biopower plant [33]. As discussed in Section 1.1, forest products in states neighboring Maine are transported 74 kilometers on average [9]. Round trip distances of between 16 kilometers and 161 kilometers were considered in this analysis, using 80 kilometers as the baseline. 
Based on information shared by a Maine logging contractor, Benjamin [37] estimated the cost per kilometer for a chip van to transport biomass chips in Maine. All of the costs, except for fuel, which is calculated by dividing the diesel fuel price by fuel economy, were considered fixed per kilometer. The fuel cost was then summed with the labor cost, repair and maintenance, payment and interest, administration, taxes, insurance, and licensing, and profit, which was then multiplied by the round trip distance and divided by the truckload mass (Equation 2.22). We calculated the final delivered biomass $\operatorname{cost}\left(C_{B}\right)$ by summing the stumpage price, biomass harvesting price, logging contractor profit, and transportation cost (Equation 2.23). This equation is the same for proportioned and non-proportioned costs, using different input values for each calculation.

$$
\begin{aligned}
& C_{T R}=\frac{\left(\frac{P_{D}}{E_{F}}+C_{L}+C_{R M}+C_{P I}+C_{A}+C_{T I L}+P_{T R}\right) * D_{T R}}{M_{T R}} \\
& C_{B}=P_{S}+C_{B H}+C_{B H} * P_{L C}+C_{T R}
\end{aligned}
$$

\section{Results}

The delivered biomass cost was calculated to be \$30/GT with harvesting costs proportioned between timber and chips and $\$ 11 / \mathrm{GT}$ with chipping only harvesting costs (Figure 3.1), using default input values (Table 1.1). The harvesting cost and logging contractor profit respectively comprised $70 \%$ and $7 \%$ of the delivered proportioned cost and $34 \%$ and $3 \%$ of the chipping only cost. These costs were much higher for the proportioned harvest cost because the feller buncher, grapple skidder, and stroke delimber costs were included. The transportation distance and stumpage price were the same for the proportioned and chipping only harvesting 
cost estimates; therefore, the delivered biomass costs for those two portions of the analysis are also the same (\$5/GT and $\$ 2 / \mathrm{GT}$, respectively) all else being equal.

In reality, harvest machine cost rates vary by logging contractor, machine purchase price, machine age, wages \& benefits, and many other factors; variations in these factors can have a sizeable impact on the final cost of harvested biomass. Varying all machine cost rates together to represent low and high values yielded respective delivered biomass estimates of $\$ 26 / \mathrm{GT}$ and $\$ 34 /$ GT for the proportioned delivered biomass cost estimate (Figure 3.2). These values are $\pm 12 \%$ from the default value presented in Figure 3.1 and represent a $28 \%$ increase from low to high. Stumpage price and transportation costs were held constant. While the low estimate was below the current delivered biomass chip price of $\$ 28 / \mathrm{GT}$, the high estimate could result in a loss of nearly $\$ 6 / G T$. In practice, however, logging contractors with higher operating costs are likely to choose to harvest blocks that will allow them to at least break even.

Varying individual machine cost rates from \$93-230/GT yielded a maximum 4\% change in delivered biomass cost from the default value of \$30/GT for the proportioned case (Figure 3.3), with the greatest (while still relatively small) variance from the stroke delimber machine cost rates. For example, a $12 \%$ increase in the stroke delimber machine cost rate increased the delivered biomass price by just over $3 \%$, resulting in a delivered biomass cost of $\$ 31 / \mathrm{GT}$. The chipper machine cost rate had the least impact on the final delivered biomass cost. For example, a $28 \%$ increase in chipper machine cost rate increased the delivered biomass price by $4 \%$, resulting in a delivered biomass cost of $\$ 31 / \mathrm{GT}$.

The proportioned delivered biomass cost was even less sensitive to changes in other input parameters, including skidding distance, skidder bunch volume, diesel price, and the round trip 
trucking distance to the end user (Figure 3.4). Variation in diesel price resulted in the largest percent change in the delivered biomass cost per percent change in input, likely due to the impact of diesel prices on both the machine cost rates and trucking cost per kilometer. Increasing the diesel price by $25 \%$ to $\$ 1.32 /$ liter (L) increased the delivered biomass price by just over $7 \%$, resulting in a delivered biomass cost of $\$ 32 / \mathrm{GT}$, a $\$ 2 / \mathrm{GT}$ increase. Diesel price changes resulted in linear delivered biomass responses, so decreasing the diesel price by $25 \%$ to $\$ 0.79 / \mathrm{L}$ decreased the delivered biomass cost by approximately $7 \%$ to $\$ 28 /$ GT. Trucking distance and profit variations also varied delivered biomass cost linearly. Increasing the average skidder bunch volume by $47 \%\left(7 \mathrm{~m}^{3}\right)$ decreased the delivered biomass cost by nearly 5\% (to $\$ 29 / \mathrm{GT}$ ), whereas decreasing the skidder bunch volume by $47 \%\left(3 \mathrm{~m}^{3}\right)$ increased the cost by $11 \%$ (to $\$ 33$ / GT), indicating that the delivered biomass cost is more sensitive to decreases in skidder bunch volumes than to increases. Increasing the average skidding distance by $100 \%$ to $610 \mathrm{~m}$ increased the delivered biomass cost by only $7 \%$ resulting in a delivered biomass cost of $\$ 32 / \mathrm{GT}$, and a 90\% decrease in skidding distance to $30 \mathrm{~m}$ decreased the delivered biomass cost by only $4 \%$ resulting in a delivered biomass cost of $\$ 29 / \mathrm{GT}$. Changes in trucker wages were not included in the sensitivity analysis or in Figure 3.4 because a $10 \%$ increase or decrease in trucking labor costs would only increase or decrease the delivered biomass cost by $0.44 \%$, or a $\$ 0.14$ change in cost. Decreasing the stumpage price by $80 \%$ to $\$ 0.40 /$ GT decreased the delivered biomass cost by nearly $6 \%$ to $\$ 28 / \mathrm{GT}$ and increasing the stumpage price by $65 \%$ resulted in nearly a $5 \%$ increase in delivered biomass cost to $\$ 32 / \mathrm{GT}$. Increasing logging contractor profit from $10 \%$ to $15 \%$ increased the delivered biomass cost by $4 \%$ to $\$ 31 / \mathrm{GT}$.

The chipping only biomass cost was more sensitive to changes in the input parameters of trucking distance, chipper machine cost rate, diesel price, stumpage price, and logger profit than 
the proportioned biomass cost (Figure 3.5). All input variations resulted in linear changes in delivered biomass cost. Increasing the round trip distance from $80 \mathrm{~km}$ to $160 \mathrm{~km}$ increased the delivered biomass cost by approximately $42 \%$ from $\$ 11 / \mathrm{GT}$ to $\$ 16 / \mathrm{GT}$. Raising the stumpage price from $\$ 2 / \mathrm{GT}$ to $\$ 5 / \mathrm{GT}(130 \%)$ increased the delivered biomass cost from $\$ 11 / \mathrm{GT}$ to $\$ 14 / \mathrm{GT}$ (26\%). A diesel price increase from $\$ 1.06 / \mathrm{L}$ to $\$ 1.59 / \mathrm{L}$ (50\%) would raise the delivered biomass $15 \%$ to $\$ 13 /$ GT. A $28 \%$ increase in chipper machine cost rate from $\$ 198 /$ GT to $\$ 253 /$ GT would result in a $10 \%$ increase in delivered biomass cost to $\$ 12 / \mathrm{GT}$. Increasing logger profit from $10 \%$ to $15 \%$ would increase the delivered biomass cost by $2 \%$ to $\$ 11 / \mathrm{GT}$.

In addition to variations in overall operating costs, stand specific characteristics including the hardwood fraction and tree size (DBH and corresponding volume) affect the proportioned delivered biomass cost in the model (Figure 3.6). Increasing the hardwood fraction to $100 \%$ (meaning that the stand is entirely hardwood species) from $40 \%$ increased the delivered biomass cost by $5.6 \%$ to $\$ 30 /$ GT. A $25 \%$ decrease in DBH class from the baseline of 20 centimeters increased the delivered cost by $32 \%$ to a delivered biomass cost of $\$ 40 / \mathrm{GT}$.

Using the input ranges from Table 1.1, the proportioned delivered biomass cost ranged from $\$ 8 /$ GT to $\$ 82 /$ GT (Figure 3.7) and the chipping only delivered biomass cost ranged from \$4/GT to \$24/GT (Figure 3.8). In practice, however, the delivered biomass prices in Maine are dependent upon the market conditions and stand characteristics. For instance, a logging contractor would most likely be unwilling to pay a stumpage price of $\$ 9 / \mathrm{GT}$ if harvesting and delivery costs were very high and the delivered biomass price did not increase substantially above the current price of $\$ 28 / \mathrm{GT}$ [24]. Additionally, it is unlikely that the delivered biomass cost would be as low as $\$ 8 / \mathrm{GT}$ as most stands in Maine have an average DBH much less than 41 
centimeters, few stands are likely to be within a round trip distance of 16 kilometers of the end user, and few stands are likely to have only softwood species in Maine.

\section{Discussion}

The proportioned and chipping only delivered biomass cost ranges from our Maine-based biomass supply chain model ( $\$ 8-82 / \mathrm{GT}$ and $\$ 4-24 / \mathrm{GT}$, respectively) are consistent with comparable values found in the literature. The logging residue costs published in the BTU included only chipping and stumpage price and excluded transport to the end user, overhead costs, and profit. The BTU indicated that all of the sustainably available logging residues in Maine could be recovered at $\$ 44 /$ dry tonne, equivalent to $\$ 22 /$ GT (assuming 50\% moisture content), or less [12]. As the BTU did not provide specific ranges for Maine and only included harvesting costs, it is difficult to determine how our Maine-based supply chain model costs compare. However, if the actual harvesting cost and opportunity costs are higher than just chipping costs, as indicated by the literature and historical delivered prices, the BTU likely overestimates the amount of biomass chips from logging residue available at $\$ 22 / \mathrm{GT}$. Other studies estimated delivered biomass costs at $\$ 26$ to $\$ 27 /$ GT (North Carolina; chipping-only and integrated with roundwood, respectively [16]) and \$18/GT (southern Alabama; excluding stumpage [17]). These literature estimates fall within the range of our mass-proportioned biomass cost estimates but are up to nearly five times higher than our non-proportioned costs (chipping only). With default machine cost rate values, our proportioned biomass cost was $\$ 30 / \mathrm{GT}$, which is $15 \%$ lower than the estimate of $\$ 35 / \mathrm{GT}$ from Benjamin et al. [24] (representing integrated pulpwood thinning and biomass harvesting in Maine before chipping, stumpage, or transportation). 


\section{Conclusions}

We developed a Maine-based biomass economic supply chain model to estimate the cost of harvesting and transporting biomass chips to the end user. The delivered cost calculated by the model varied from $\$ 8-82 / \mathrm{GT}$ if the harvesting costs are proportioned between timber and biomass chips and \$4-24/GT if only chipping costs are included for biomass harvesting, depending on stumpage prices, machine cost rates, harvesting productivity, site characteristics, diesel prices, and the distance to the end user. The delivered cost of biomass was below the current biomass chip price of $\$ 28 / \mathrm{GT}$ when biomass was treated as a waste product and within the range of the current price or higher when harvesting costs were included. These results are generally consistent with literature results, but our results provide a more complete exploration of how factors along the supply chain may impact the delivered price, particularly in the Northeast. Further research is needed to determine whether harvesting costs proportioned across products or chipping only harvesting costs better reflect the true cost of biomass harvesting in Maine. While FRCS-based studies assume biomass from logging residues is a waste product and only include chipping costs, other literature emphasize the importance of including the opportunity cost of collecting residues rather than higher valued timber products.

In addition, research involving the willingness of logging contractors to expand into the biomass market in Maine, harvest system innovation, and the productivity and cost estimation of innovative biomass harvesting systems should be further explored. Stone et al. [38] found that innovative logging contractors in Maine were most concerned about market price and access, market stability, and the cost of innovating. Understanding the factors that influence whether or not logging contractors are willing to harvest biomass and the delivered price they are willing to 
accept are important next steps for verifying the biomass supply chain model and biomass harvesting estimates for Maine.

This work is part of a larger research effort to assess the technical, economic, environmental, and social sustainability implications of a new biofuel development pathway in Maine. The economic supply chain model described here will be expanded to estimate the cost of the delivered biofuel to a fueling station, and the final model will be integrated with an environmental life cycle assessment and social science research to assess the overall sustainability of the new pathway. Although this study has focused on Maine, the model is applicable to other regions of the US and world with woody biomass.

\section{Acknowledgements}

This research was primarily supported by the Forest Bioproducts Research Institute under the National Science Foundation (NSF) Sustainable Energy Pathways (SEP) award 1230908 and the USDA National Institute of Food and Agriculture Hatch project 0230040 and also partially supported through NSF grant EPS-0554545, National Institute of Food and Agriculture (NIFA) Award 2012-10008-20271, Agricultural Research Service (ARS) project 1935-41000-082-15A. The authors would also like to thank Jonathan Rubin and Binod Neupane from the University of Maine for their input in the development of this project. 


\section{REFERENCES}

[1] R. Schnepf, B.D. Yacobucci, Renewable Fuel Standard (RFS): Overview and Issues, Congressional Research Service, Washington, D.C., 2013. http://www.fas.org/sgp/crs/misc/R40155.pdf.

[2] G.L. McCaskill, W.H. McWilliams, C.J. Barnett, B.J. Butler, M.A. Hatfield, C.M. Kurtz, et al. Maine's Forests 2008, U.S. Forest Service, 2011.

[3] C.M. Dickerson, Energy in Maine, Margaret Chase Smith Policy Center, Orono, ME, 2012. http://mcspolicycenter.umaine.edu/files/pdf/Energy\%20in\%20Maine,\%20final\%2015Feb20 12.pdf.

[4] MFS, 2011 Silvicultural Activities Report Including Annual Report on Clearcutting and Precommercial Activities, Forest Policy and Management Division, Maine Forest Service, Department of Agriculture, Augusta, Maine, 2013. http://www.maine.gov/doc/mfs/pubs/pdf/silvi/11silvi.pdf (accessed March 14, 2013).

[5] National Research Council, Renewable Fuel Standard: Potential Economic and Environmental Effects of U.S. Biofuel Policy, The National Academies Press, Washington, DC, 2011. http://www.nap.edu/catalog.php?record_id=13105 (accessed May 15, 2014).

[6] R.D. Houx, Revolutionary process for biofuel discovered at UMaine, Orono, Maine Insights. (2011). http://maineinsights.com/perma/revolutionary-process-for-biofueldiscovered-at-umaine-orono (accessed May 12, 2014).

[7] Stumpage Prices by Maine County/Unit, 2012, Maine Forest Service and Maine Department of Agriculture, Conservation and Forestry, 2013. http://statedocs.maine.gov/for_docs/2.

[8] Northern Research Station, Maine's Forests 2008: Statistics, Methods and Quality Assurance, Northern Research Station, Forest Service, USDA, 2008.

http://www.nrs.fs.fed.us/fia/data-tools/statereports/ME/docs/MaineForests2008_StatisticsandQualityAssurance.pdf.

[9] B.H. Leon, J.G. Benjamin, A Survey of Business Attributes, Harvest Capacity and Equipment Infrastructure of Logging Businesses in the Northern Forest, The University of Maine, School of Forest Resources, Orono, ME, 2012.

[10] M. Moesswilde, Best Management Practices for Forestry: Protecting Maine's Water Quality, Maine Forest Service, Department of Conservation, Forest Policy and Management Division, 2004.

[11] K. Skog, J. Barbour, M. Buford, D. Dykstra, P. Lebow, P. Miles, B. Perlack, B. Stokes, Forest-Based Biomass Supply Curves for the United States, J. Sustain. For. 32 (2013) 1427. doi:10.1080/10549811.2011.651780.

[12] DOE, US Billion Ton Update: Biomass Supply for a Bioenergy and Bioproducts Industry, Oak Ridge National Laboratory, Oak Ridge, TN, 2011. http://www1.eere.energy.gov/biomass/pdfs/billion_ton_update.pdf.

[13] N. Anderson, W. Chung, D. Loeffler, J. Jones, J. Greg, A Productivity and Cost Comparison of Two Systems for Producing Biomass Fuel from Roadside Forest Treatment Residues, For. Prod. J. 62 (2012) 222.

[14] M.C. Bolding, L.D. Kellogg, C.T. Davis, Productivity and costs of an integrated mechanical forest fuel reduction operation in southwest Oregon, For. Prod. J. 59 (2009) 35. 
[15] H. Harrill, H.-S. Han, Productivity and Cost of Integrated Harvesting of Wood Chips and Sawlogs in Stand Conversion Operations, Int. J. For. Res. 2012 (2012). doi:10.1155/2012/893079.

[16] J.L. Conrad IV, M.C. Bolding, W.M. Aust, R.L. Smith, A. Horcher, Harvesting productivity and costs when utilizing energywood from pine plantations of the southern Coastal Plain USA, Biomass Bioenergy. 52 (2013) 85-95. doi:10.1016/j.biombioe.2013.02.038.

[17] P. Jernigan, T. Gallagher, J. Aulakh, R. Tufts, T. McDonald, Implementing residue chippers on harvesting operations in the southeastern US for biomass recovery, Int. J. For. Eng. 24 (2013) 129-136. doi:10.1080/14942119.2013.798130.

[18] T.H. Stasko, R.J. Conrado, A. Wankerl, R. Labatut, R. Tasseff, J.T. Mannion, et al., Mapping woody-biomass supply costs using forest inventory and competing industry data, Biomass Bioenergy. 35 (2011) 263-271. doi:10.1016/j.biombioe.2010.08.044.

[19] D. Abbas, D. Current, M. Ryans, S. Taff, H. Hoganson, K.N. Brooks, Harvesting forest biomass for energy - An alternative to conventional fuel treatments: Trials in the Superior National Forest, USA, Biomass Bioenergy. 35 (2011) 4557-4564. doi:10.1016/j.biombioe.2011.06.030.

[20] D.R. Becker, K. Skog, A. Hellman, K.E. Halvorsen, T. Mace, An outlook for sustainable forest bioenergy production in the Lake States, Energy Policy. 37 (2009) 5687-5693. doi:10.1016/j.enpol.2009.08.033.

[21] P.B. Woodbury, T. Volk, R.H. Germain, P. Castellano, T. Buchholz, J. Wightman, et al., Renewable Fuels Roadmap Appendix E: Analysis of Sustainable Feedstock Production in New York State, The New York State Energy Research and Development Authority, 2010. http://www.nyserda.ny.gov/Publications/Research-and-Development-TechnicalReports/Biomass-Reports/Renewable-Fuels-Roadmap.aspx (accessed May 15, 2014).

[22] P. Hiesl, J.G. Benjamin, A multi-stem feller-buncher cycle-time model for partial harvest of small-diameter wood stands, Int. J. For. Eng. 24 (2013) 101-108. doi:10.1080/14942119.2013.841626.

[23] P. Hiesl, J.G. Benjamin, Harvesting Equipment Cycle Time and Productivity Guide for Logging Operations in Maine, The University of Maine, Cooperative Forestry Research Unit, Orono, ME, 2013.

[24] J.G. Benjamin, R. Seymour, E. Meacham, J. Wilson, Impact of whole-tree and cut-to-length harvesting on post-harvest condition and logging costs for early commercial thinning in Maine, North. J. Appl. For. 30 (2013) 149-155. doi:10.5849/njaf.13-016.

[25] J.G. Benjamin, R.J. Lilieholm, C.E. Coup, Forest Biomass Harvesting in the Northeast: A Special-Needs Operation?, North. J. Appl. For. 27 (2010) 45-49.

[26] D. Dykstra, Batch Processing in FRCS, Pacific Northwest Research Station, USDA Forest Service, 2010. http://www.fs.fed.us/pnw/data/frcs/FRCS-BatchProcessingInstructions.pdf.

[27] P. Hiesl, J.G. Benjamin, Applicability of International Harvesting Equipment Productivity Studies in Maine, USA: A Literature Review, Forests. 4 (2013) 898-921. doi:10.3390/f4040898.

[28] D. Abbas, R. Handler, D. Dykstra, B. Hartsough, P. Lautala, Cost Analysis of Forest Biomass Supply Chain Logistics, J. For. 111 (2013) 271-281. doi:10.5849/jof.12-054.

[29] R Core Team, R: A language and environment for statistical computing, R Foundation for Statistic Computing, Vienna, Austria, 2013. http://www.R-project.org.

[30] J.G. Benjamin, Maine Chipping Productivity Estimates, (2014). 
[31] K.M. Laustsen, Forest Biomass Estimates in Maine: Statewide, County, and Spatial. Maine Agricultural and Forest Experiment Station, The University of Maine; 2008.

[32] J.G. Benjamin, P. Hiesl, Harvesting Equipment Productivity Study 2012: Summary for Whole-Tree Systems and Cut-to-Length Systems in Maine. Orono, ME: Cooperative Forestry Research Unit, University of Maine; 2012.

[33] Maine Wood-to-Energy Task Force, The Governor's Wood-to-Energy Task Force Report, Augusta, Maine, 2008.

http://www.maineenergysystems.com/userfiles/files/Wood\%20to\%20Energy\%20Task\%20 Force\%20Report.pdf.

[34] R.W. Brinker, J. Kinard, R. Rummer, B. Lanford, Machine rates for selected forest harvesting machines, Alabama Agricultural Experiment Station, Auburn University, Auburn, Alabama, 2002. http://www.treesearch.fs.fed.us/pubs/33467 (accessed May 31, 2013).

[35] J.I. Briedis, J.S. Wilson, J.G. Benjamin, R.G. Wagner, Biomass retention following wholetree, energy wood harvests in central Maine: Adherence to five state guidelines, Biomass Bioenergy. 35 (2011) 3552-3560. doi:10.1016/j.biombioe.2011.05.018.

[36] R.E. Eckardt, Renewable Biomass from the Forests of Massachusetts: Forest Harvesting Systems for Biomass Production, Innovative Natural Resource Solutions LLC, Massachusetts Sustainable Forest Bioenergy Initiative, Portland, ME, 2007.

[37] J.G. Benjamin, Operational \& Economic Aspects of Biomass Harvesting: "There is No Free Lunch in the Woods," (2014).

[38] I.J. Stone, J.G. Benjamin, J.E. Leahy, Innovation Impacts on Biomass Supply in Maine's Logging Industry, For. Prod. J. 61 (2011) 579-585.

[39] B.M. O’Connell, E.B. LaPoint, J.A. Turner, T. Ridley, D. Boyer, A.M. Wilson, et al., The Forest Inventory and Analysis Database: Database Description and Users Manual Version 5.1.6 for Phase 2, USDA Forest Service, 2013. http://www.fia.fs.fed.us/library/databasedocumentation/current/ver5.1.6/FIADB_user\%20manual_5-1-6_p2_7_12_2013_all.pdf (accessed May 5, 2014).

[40] P.D. Miles, Forest Inventory EVALIDator web-application, U.S. Department of Agriculture, Forest Service, Northern Research Station, St. Paul, MN, 2014. http://apps.fs.fed.us/Evalidator/tmattribute.jsp.

[41] EIA, Weekly Retail Gasoline Diesel Prices for New England, (2014). http://www.eia.gov/dnav/pet/pet_pri_gnd_dcus_r1x_m.htm (accessed April 27, 2014).

[42] Bureau of Labor Statistics, May 2013 State Occupational Employment and Wage Estimates: Maine, Occup. Employ. Stat. (2014). http://www.bls.gov/oes/current/oes_me.htm (accessed April 28, 2014).

[43] D. Dykstra, Fuel Reduction Cost Simulator - North, 2010. http://www.fs.fed.us/pnw/data/frcs/frcs.shtml. 


\begin{tabular}{|c|c|c|c|c|c|}
\hline Symbol & Description & Units & $\operatorname{Min}^{\mathbf{a}}$ & Default $^{b}$ & $\operatorname{Max}$ \\
\hline \multicolumn{6}{|c|}{ Harvest } \\
\hline$C_{B H p}$ & $\begin{array}{l}\text { Cost of biomass harvest, proportioned by } \\
\text { timber harvest equipment }\end{array}$ & $\$ / G T$ & \multicolumn{3}{|c|}{ calculated } \\
\hline$C_{B H n p}$ & $\begin{array}{l}\text { Cost of biomass harvest, non-proportioned } \\
\text { (chipper only) }\end{array}$ & $\$ / G T$ & \multicolumn{3}{|c|}{ calculated } \\
\hline$c_{i}$ & Unit cost of specific machine (i) & $\$ / \mathrm{PMH}$ & \multicolumn{3}{|c|}{ varies - see Table 1.2} \\
\hline$C_{i, V}$ & $\begin{array}{l}\text { Cost of machine (i) per unit volume } \\
\text { harvested by machine }\end{array}$ & $\$ / \mathrm{m}^{3}$ & \multicolumn{3}{|c|}{ calculated } \\
\hline$C_{i, A}$ & $\begin{array}{l}\text { Cost of machine (i) per unit area harvested } \\
\text { by machine }\end{array}$ & $\$ / \mathrm{km}^{2}$ & \multicolumn{3}{|c|}{ calculated } \\
\hline$C_{H}$ & Cost of harvest per unit area & $\$ / \mathrm{km}^{2}$ & \multicolumn{3}{|c|}{ calculated } \\
\hline$C_{T H, V}$ & Cost of timber harvest per unit volume & $\$ / \mathrm{m}^{3}$ & \multicolumn{3}{|c|}{ calculated } \\
\hline$C_{T H p}$ & Cost of timber harvest, proportioned & $\$ / \mathrm{km}^{2}$ & \multicolumn{3}{|c|}{ calculated } \\
\hline$C_{T H n p}$ & Cost of timber harvest, non-proportioned & $\$ / \mathrm{m}^{3}$ & \multicolumn{3}{|c|}{ calculated } \\
\hline$C F_{K G T}$ & $\begin{array}{l}\text { Conversion Factor - kilograms per metric } \\
\text { ton }\end{array}$ & $\mathrm{kg} /$ tonne & NA & 1,000 & NA \\
\hline$C F_{M F T 3}$ & Conversion Factor $-\mathrm{m}^{3}$ per $\mathrm{ft}^{3}$ & $\mathrm{~m}^{3} / \mathrm{ft}^{3}$ & NA & 0.0283168 & NA \\
\hline$C F_{M H R}$ & Conversion Factor - minutes per hour & minutes/ hour & NA & 60 & NA \\
\hline$D B H$ & $\begin{array}{l}\text { Average tree diameter at breast height } \\
(\mathrm{DBH})^{\mathrm{c}}\end{array}$ & $\mathrm{cm}$ & 41 & 20 & 15 \\
\hline$D_{s}$ & $\begin{array}{l}\text { Skidding distance: average distance } \\
\text { grapple skidder travels from landing to } \\
\text { pick up each bunch of trees }\end{array}$ & $\mathrm{m}$ & $30[23]$ & $305[24]$ & $762[23]$ \\
\hline$f_{B}$ & $\begin{array}{l}\text { Biomass fraction: percentage of tree by } \\
\text { weight made up of the limbs and tree tops }\end{array}$ & $\%$ & NA & $23 \%[31]$ & NA \\
\hline$f_{B H}$ & Fraction of total harvest that is biomass & $\%$ & \multicolumn{3}{|c|}{ calculated } \\
\hline$f_{B R}$ & $\begin{array}{l}\text { Biomass recovery fraction: percentage of } \\
\text { biomass recovered using the WT method }\end{array}$ & $\%$ & $70 \%$ & $55 \%$ & $40 \%$ \\
\hline$f_{H W}$ & $\begin{array}{l}\text { Hardwood fraction: number of hardwood } \\
\text { trees divided by total number of trees }\end{array}$ & NA & 0 & 0.4 & 1 \\
\hline$f_{H R}$ & $\begin{array}{l}\text { Tree harvest removal fraction: percentage } \\
\text { of trees harvested from the stand }\end{array}$ & $\%$ & $16 \%[32]$ & $40 \%$ & $\begin{array}{r}66 \% \\
{[32]}\end{array}$ \\
\hline$f_{T H}$ & Fraction of total harvest that is timber & $\%$ & \multicolumn{3}{|c|}{ calculated } \\
\hline$M_{B H}$ & Mass of biomass harvested per unit area & $\mathrm{GT} / \mathrm{km}^{2}$ & \multicolumn{3}{|c|}{ calculated } \\
\hline$M_{H}$ & Mass of harvest per unit area & $\mathrm{GT} / \mathrm{km}^{2}$ & \multicolumn{3}{|c|}{ calculated } \\
\hline$M_{T H}$ & Mass of timber harvested per unit area & $\mathrm{GT} / \mathrm{km}^{2}$ & \multicolumn{3}{|c|}{ calculated } \\
\hline$N_{t}$ & Number of trees per unit area & Trees/ km² & NA & 35600 & NA \\
\hline
\end{tabular}




\begin{tabular}{|c|c|c|c|c|c|}
\hline$N_{t H}$ & Number of trees harvested per unit area & Trees/ $\mathrm{km}^{2}$ & \multicolumn{3}{|c|}{ calculated } \\
\hline$\rho$ & Wood density & $\mathrm{kg} / \mathrm{m}^{3}$ & NA & 961 & NA \\
\hline$P_{i}$ & Machine (i) productivity & $\mathrm{m}^{3} / \mathrm{PMH}$ & \multicolumn{3}{|c|}{ varies - see Table 1.2} \\
\hline$P_{L C}$ & Logging contactor profit and overhead & $\%$ & 5 & 10 & 15 \\
\hline$P_{S}$ & Biomass stumpage price & $\$ / G T$ & $\$ 0.44[7]$ & $\$ 2.29$ & $\$ 8.82$ \\
\hline$V_{B H}$ & Biomass volume harvested per unit area & $\mathrm{m}^{3} / \mathrm{km}^{2}$ & \multicolumn{3}{|c|}{ calculated } \\
\hline$V_{t S B}$ & $\begin{array}{l}\text { Skidding bunch volume: average tree } \\
\text { bunch volume transported by grapple } \\
\text { skidder from forest to landing }\end{array}$ & $\mathrm{m}^{3}$ & $8[23]$ & $5[23]$ & $1[23]$ \\
\hline$V_{t}$ & Average tree volume & $\mathrm{m}^{3}$ & 0.9 & 0.2 & 0.1 \\
\hline$V_{T H}$ & Volume of timber harvested per unit area & $\mathrm{m}^{3} / \mathrm{km}^{2}$ & \multicolumn{3}{|c|}{ calculated } \\
\hline$V_{H}$ & Volume of harvest per unit area & $\mathrm{m}^{3} / \mathrm{km}^{2}$ & \multicolumn{3}{|c|}{ calculated } \\
\hline \multicolumn{6}{|c|}{ Transportation } \\
\hline$C_{A}$ & Cost of administration & $\$ / \mathrm{km}$ & NA & $\$ 0.07$ & NA \\
\hline$C_{L}$ & Cost of trucking labor & $\$ / \mathrm{km}$ & NA & $\$ 0.50$ & NA \\
\hline$C_{R M}$ & Cost of repair \& maintenance on truck & $\$ / \mathrm{km}$ & NA & $\$ 0.23$ & NA \\
\hline$C_{P I}$ & Cost of payment and interest for truck & $\$ / \mathrm{km}$ & NA & $\$ 0.21$ & NA \\
\hline$C_{T L L}$ & Cost of taxes, insurance \& licensing & $\$ / \mathrm{km}$ & NA & $\$ 0.05$ & NA \\
\hline$C_{T R}$ & Trucking cost & $\$ / G T$ & \multicolumn{3}{|c|}{ calculated } \\
\hline$D_{T R}$ & Round trip trucking distance & $\mathrm{km}$ & 16 & $80[9]$ & $161[33]$ \\
\hline$E_{F}$ & $\begin{array}{l}\text { Fuel economy of trucks transporting } \\
\text { biomass from forest to end-use }\end{array}$ & $\mathrm{km}$ per liter & NA & 1.786 & NA \\
\hline$M_{T R}$ & Truckload mass & GT/load & NA & 32 & NA \\
\hline$P_{D}$ & Diesel price & $\$ /$ liter & $\$ 0.90$ & $\$ 1.10$ & $\$ 1.60$ \\
\hline$P_{T R}$ & Profit associated with trucking & $\$ / \mathrm{km}$ & NA & $\$ 0.02$ & NA \\
\hline
\end{tabular}

${ }^{a}$ Minimum and Maximum refer to delivered biomass cost, not to input values; in some cases, the minimum input value was used to calculate the maximum delivered cost and vice-versa.

${ }^{b}$ Based on 80-kilometer radius around Old Town facility

${ }^{c}$ Measured at 1 meter above ground [2]

GT $=$ green tonne

$P M H=$ productive machine hour

$N A=$ not applicable 


\begin{tabular}{|lllrrr|}
\hline Symbol & Description & Units & \multicolumn{1}{c|}{ Min } & Default & Max \\
\hline $\mathrm{C}_{\mathrm{CH}}$ & Chipper cost & $\$ / \mathrm{PMH}$ & $\$ 129$ & $\$ 179$ & $\$ 229$ \\
$\mathrm{C}_{\mathrm{FB}}$ & Feller buncher cost & $\$ / \mathrm{PMH}$ & $\$ 103$ & $\$ 123$ & $\$ 143$ \\
$\mathrm{C}_{\mathrm{GS}}$ & Grapple skidder cost & $\$ / \mathrm{PMH}$ & $\$ 93$ & $\$ 103$ & $\$ 113$ \\
$\mathrm{C}_{\mathrm{L}}$ & Loader cost & $\$ / \mathrm{PMH}$ & $\$ 96$ & $\$ 121$ & $\$ 146$ \\
$\mathrm{C}_{\mathrm{SD}}$ & Stroke delimber cost & $\$ / \mathrm{PMH}$ & $\$ 115$ & $\$ 131$ & $\$ 147$ \\
$\mathrm{P}_{\mathrm{FB}}$ & Feller buncher & productivity & $\mathrm{m}^{3} / \mathrm{PMH}$ & \multicolumn{3}{c}{ Calculated } \\
$\mathrm{P}_{\mathrm{GS}}$ & Grapple skidder & productivity & $\mathrm{m}^{3} / \mathrm{PMH}$ & \multicolumn{3}{c}{ Calculated } \\
$\mathrm{P}_{\mathrm{L}}$ & Loader productivity & $\mathrm{m}^{3} / \mathrm{PMH}$ & \multicolumn{3}{c}{ Calculated } \\
$\mathrm{P}_{\mathrm{C}}$ & Chipper productivity & $\mathrm{GT} / \mathrm{PMH}$ & $86[30]$ & 48 [30] & $24[30]$ \\
$\mathrm{P}_{\mathrm{SD}}$ & Stroke delimber & productivity & $\mathrm{m}^{3} / \mathrm{PMH}$ & \multicolumn{3}{c}{ Calculated } \\
\hline
\end{tabular}


Figure 1.1. Biomass Supply Chain Costs Cost of biomass delivered to purchasing facility (i.e., electricity generator, biorefinery)

Figure 2.1. Proportioned Harvesting Cost Methodology

Figure 2.2. Chipping Only Harvesting Cost Methodology ${ }^{1}$

Figure 3.1. A Comparison of Proportioned and Chipping Only Baseline Costs

Figure 3.2. Proportioned Delivered Biomass Costs for Low, Average, and High Machine Rates (\$/GT)

Figure 3.3. Sensitivity of Proportioned Delivered Biomass Cost to Changes in Harvest Machine Rate Cost

Figure 3.4. Sensitivity of Proportioned Delivered Biomass Cost to Non-Stand Specific Inputs

Figure 3.5. Sensitivity of Chipping Only Delivered Biomass Cost to Changes in Non-Stand Specific Inputs

Figure 3.6. Sensitivity of Proportioned Delivered Biomass Cost to Changes in Stand Specific Inputs

Figure 3.7. Low and High Delivered Biomass Cost with Harvest Costs Proportioned between Products

Figure 3.8. High and Low Delivered Biomass Cost with Harvest Costs Including Only Chipping

\footnotetext{
${ }^{1}$ Biomass costs and timber costs are reported per GT for ease in comparability; however, in the model timber costs are reported per $\mathrm{m}^{3}$ due to conventions.
} 


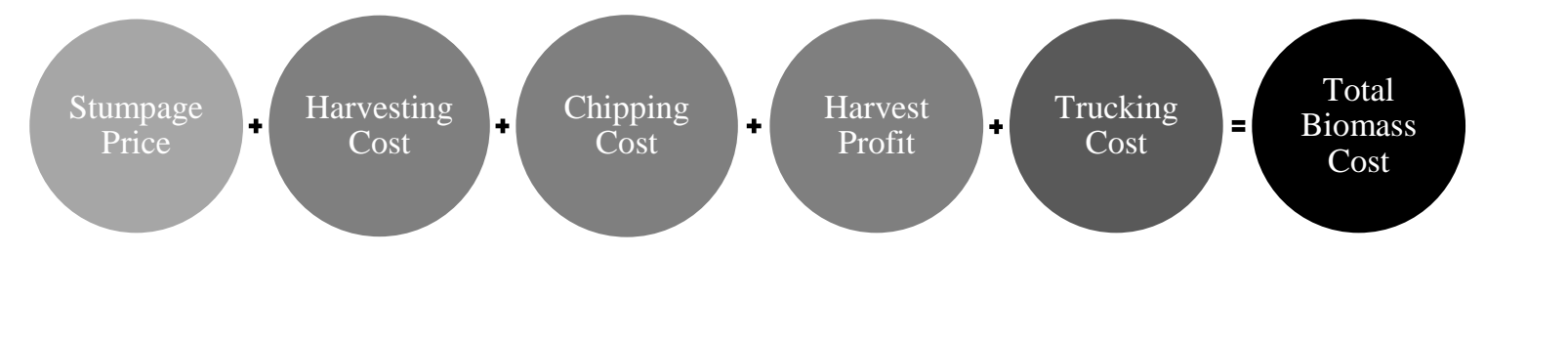

Figure 1.1

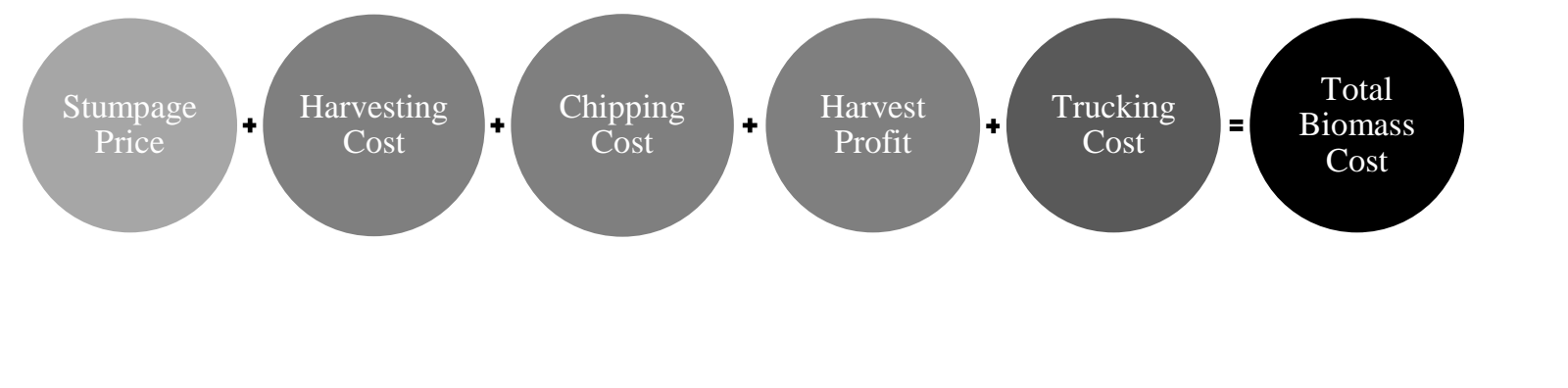

(

(

0000

-

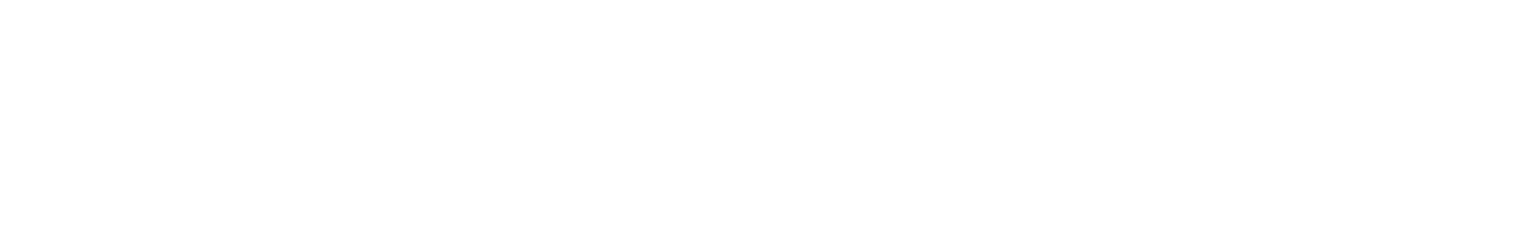

.

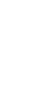

.
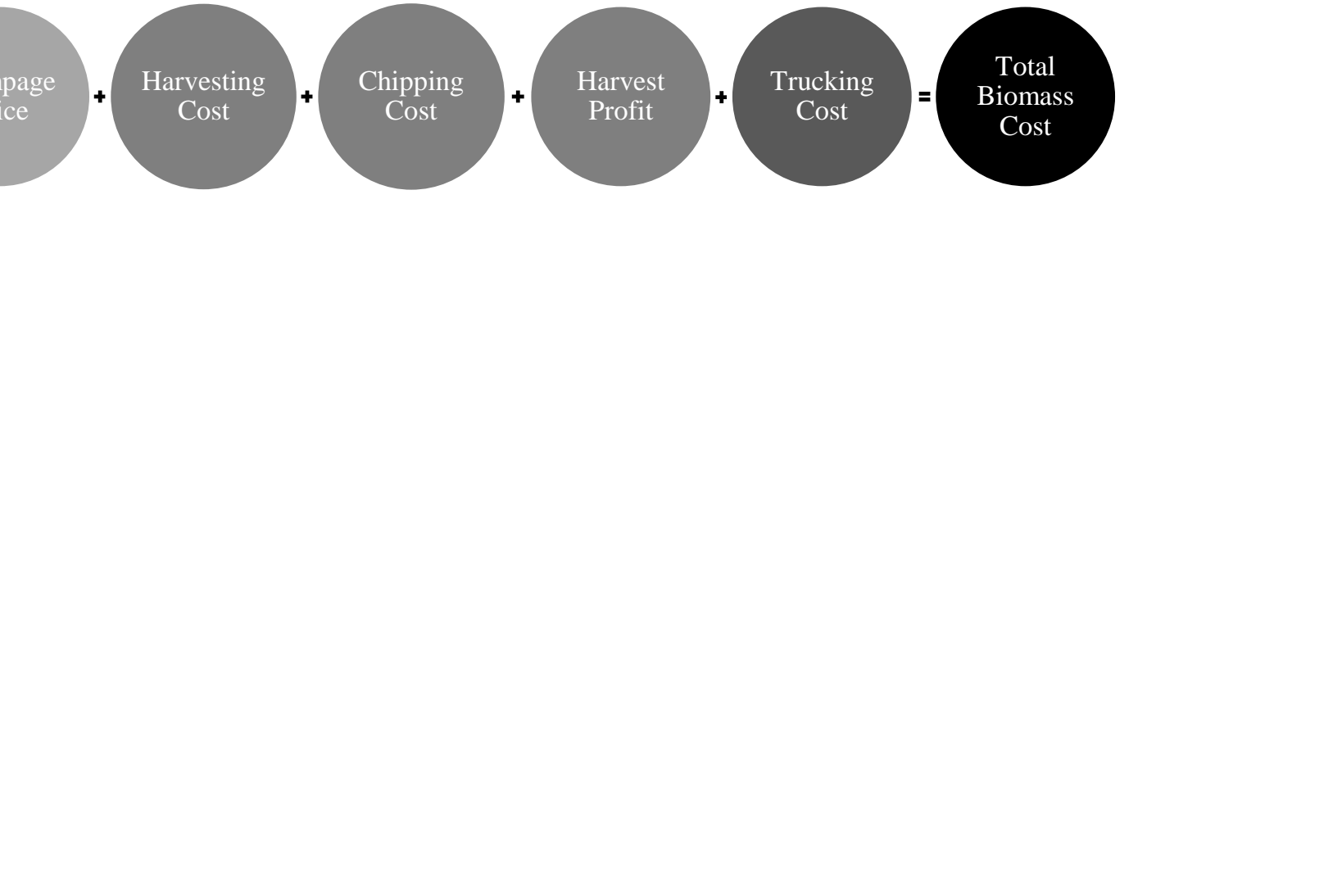


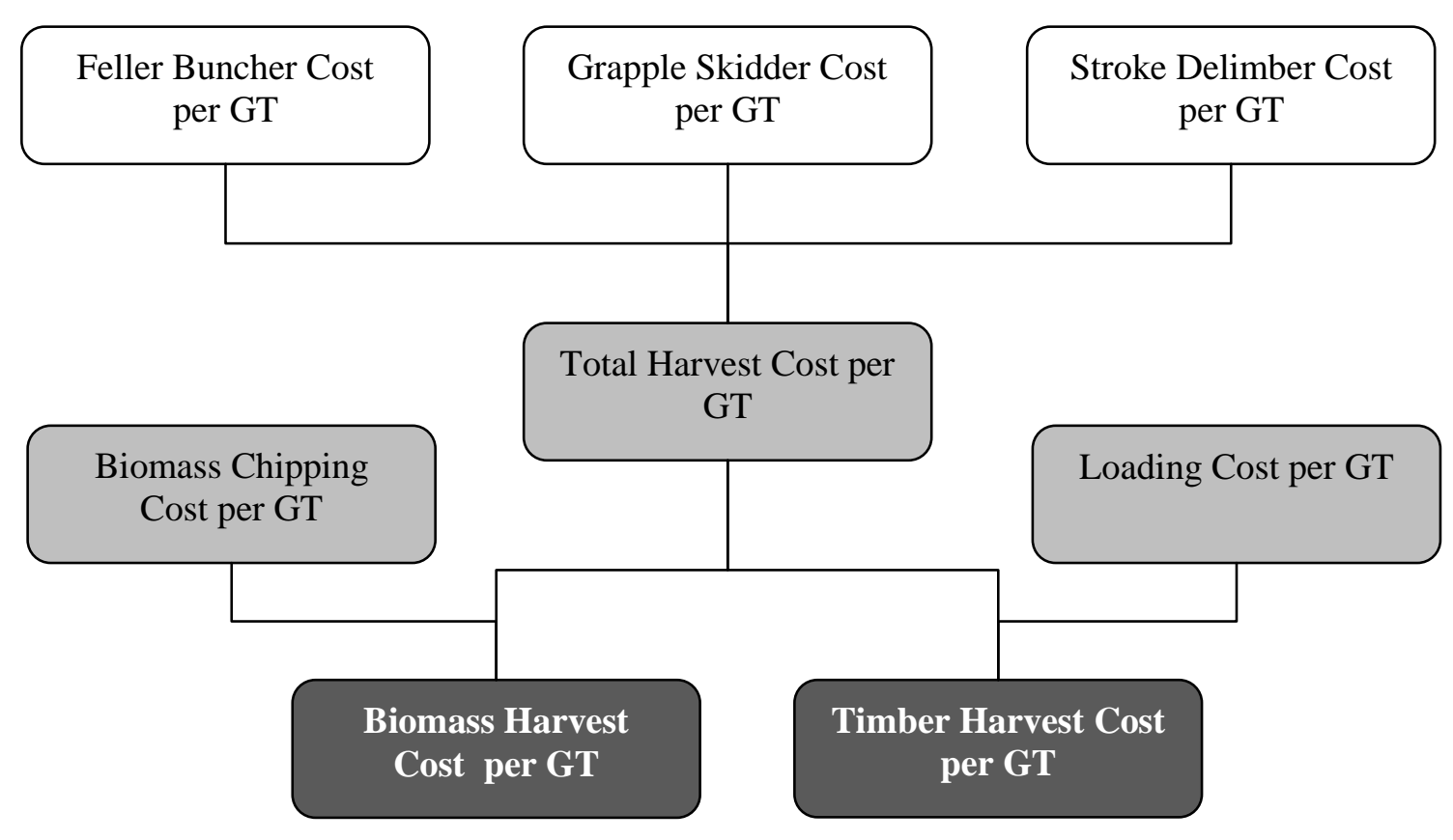




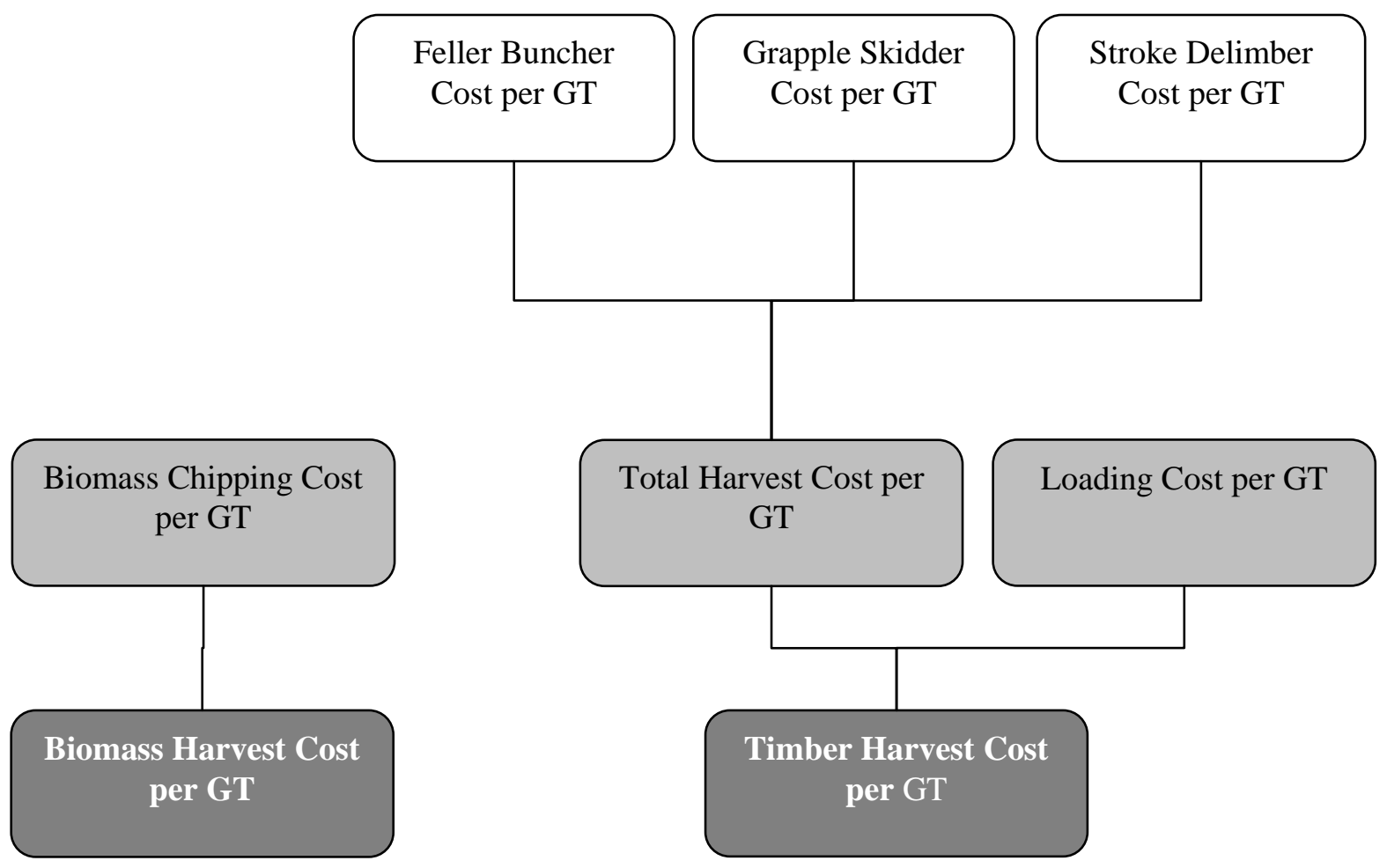


Figure 3.1

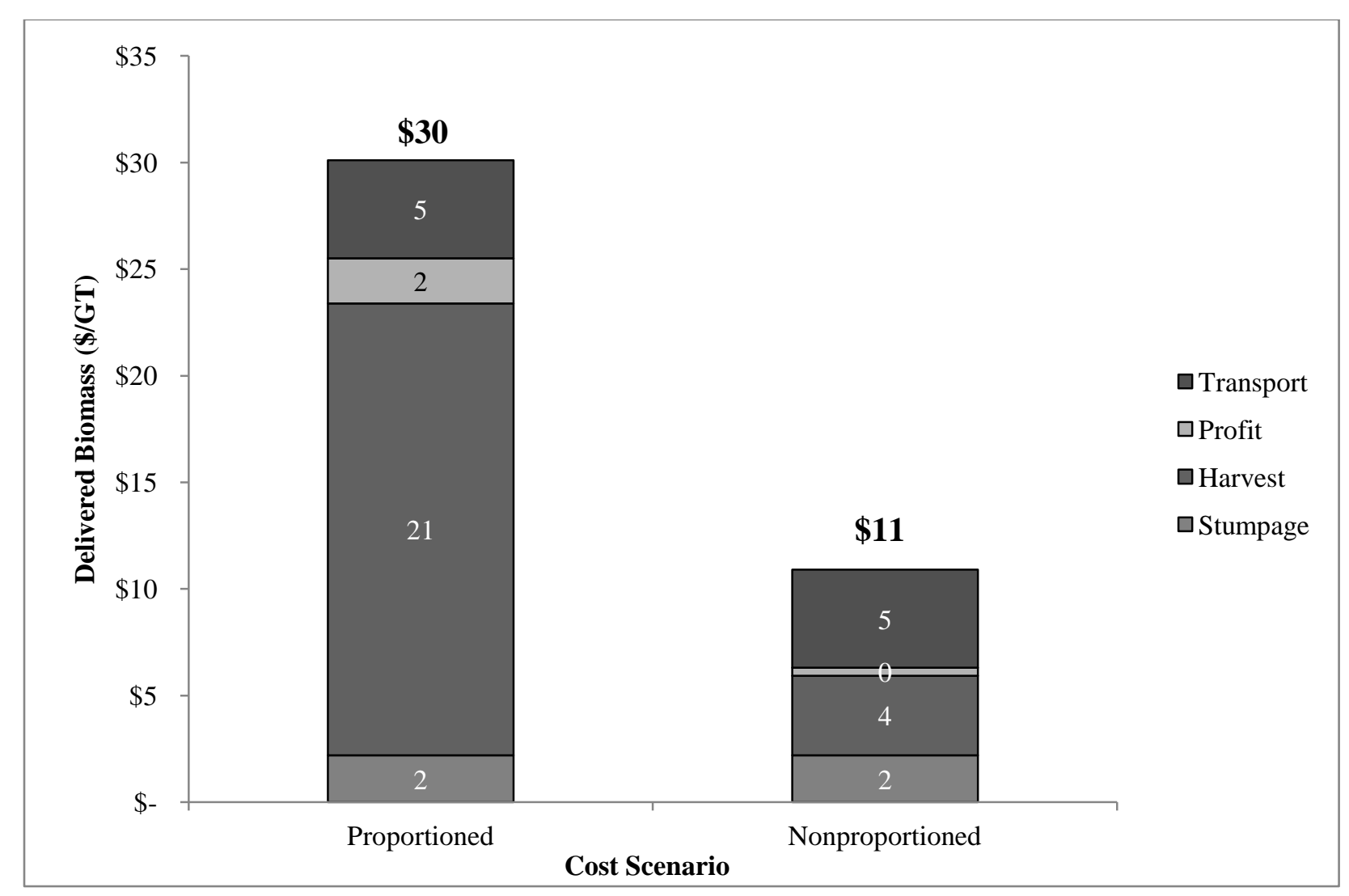


Figure 3.2

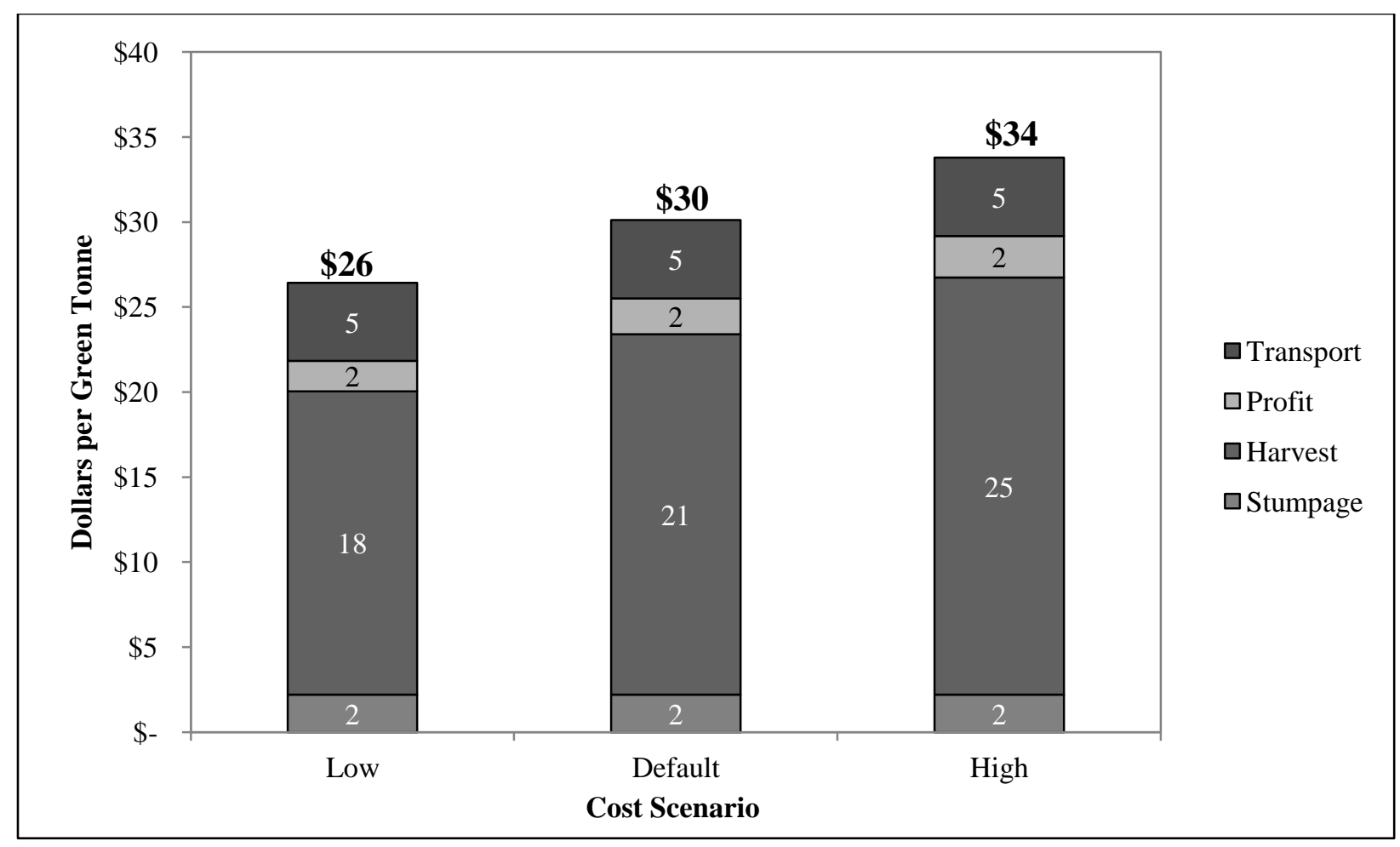


Figure 3.4

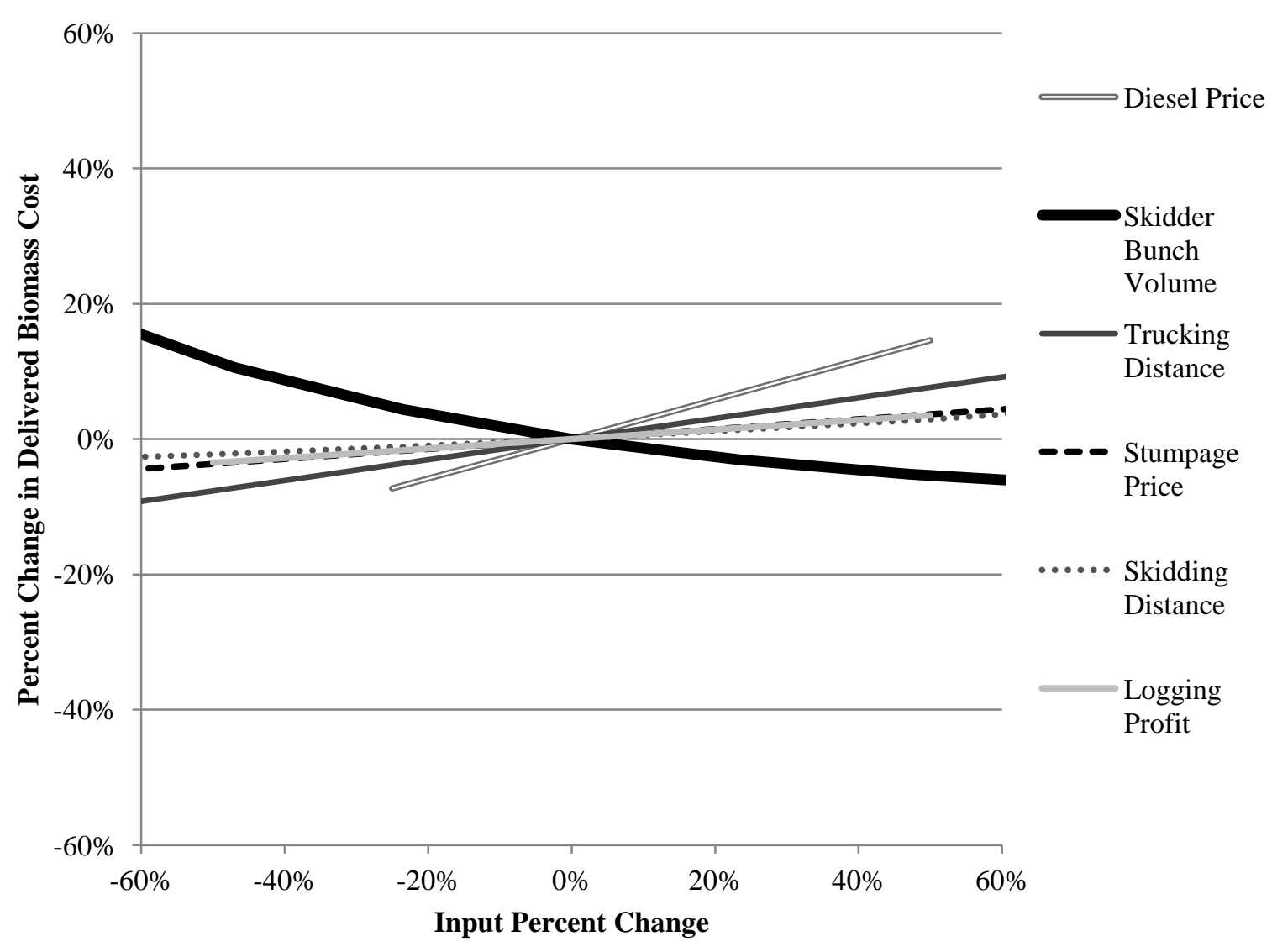

$*$ The baseline delivered biomass cost $(0,0)$ is $\$ 30$ per GT. 


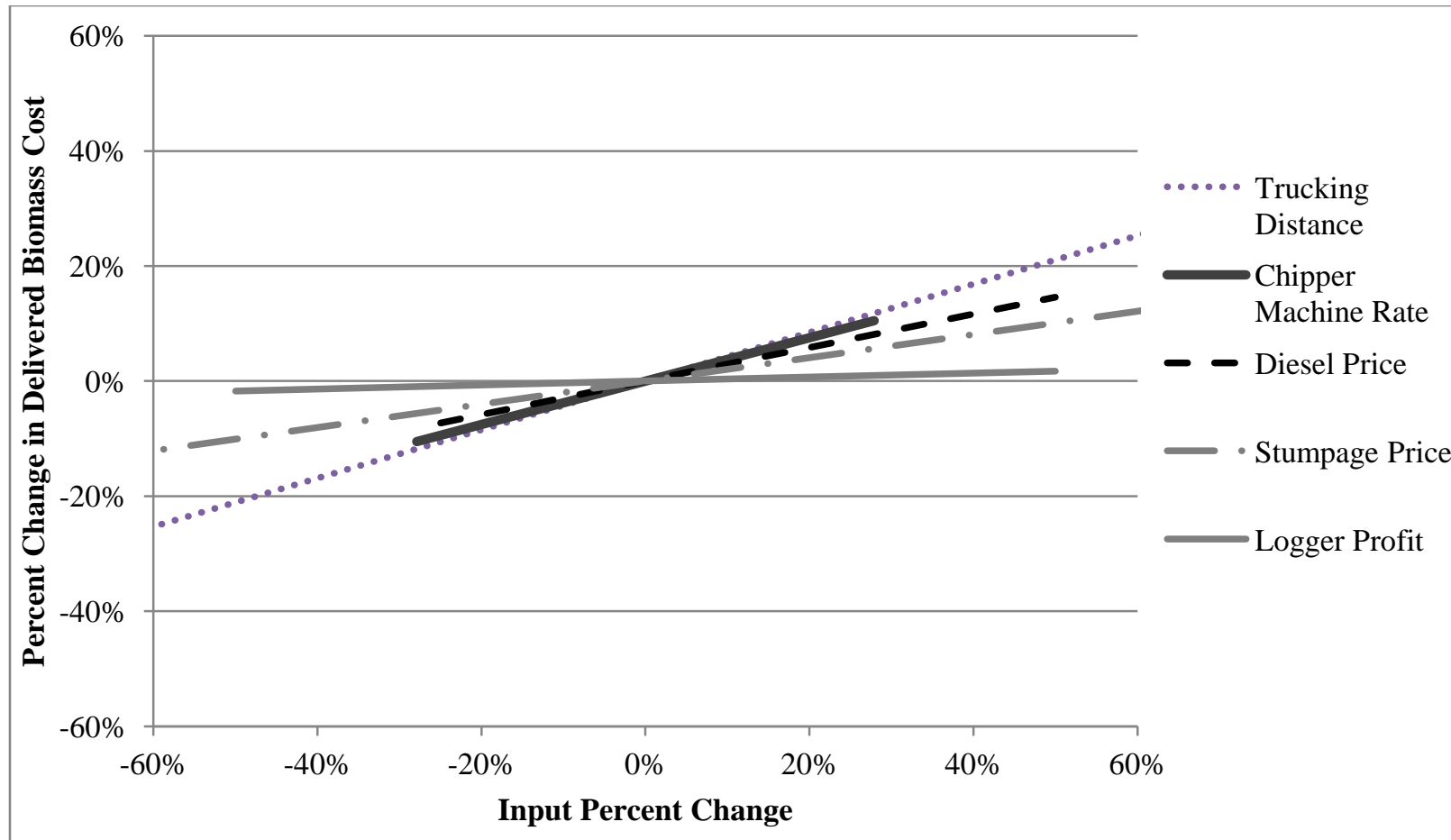

*The baseline delivered biomass cost $(0,0)$ is $\$ 11$ per GT. 


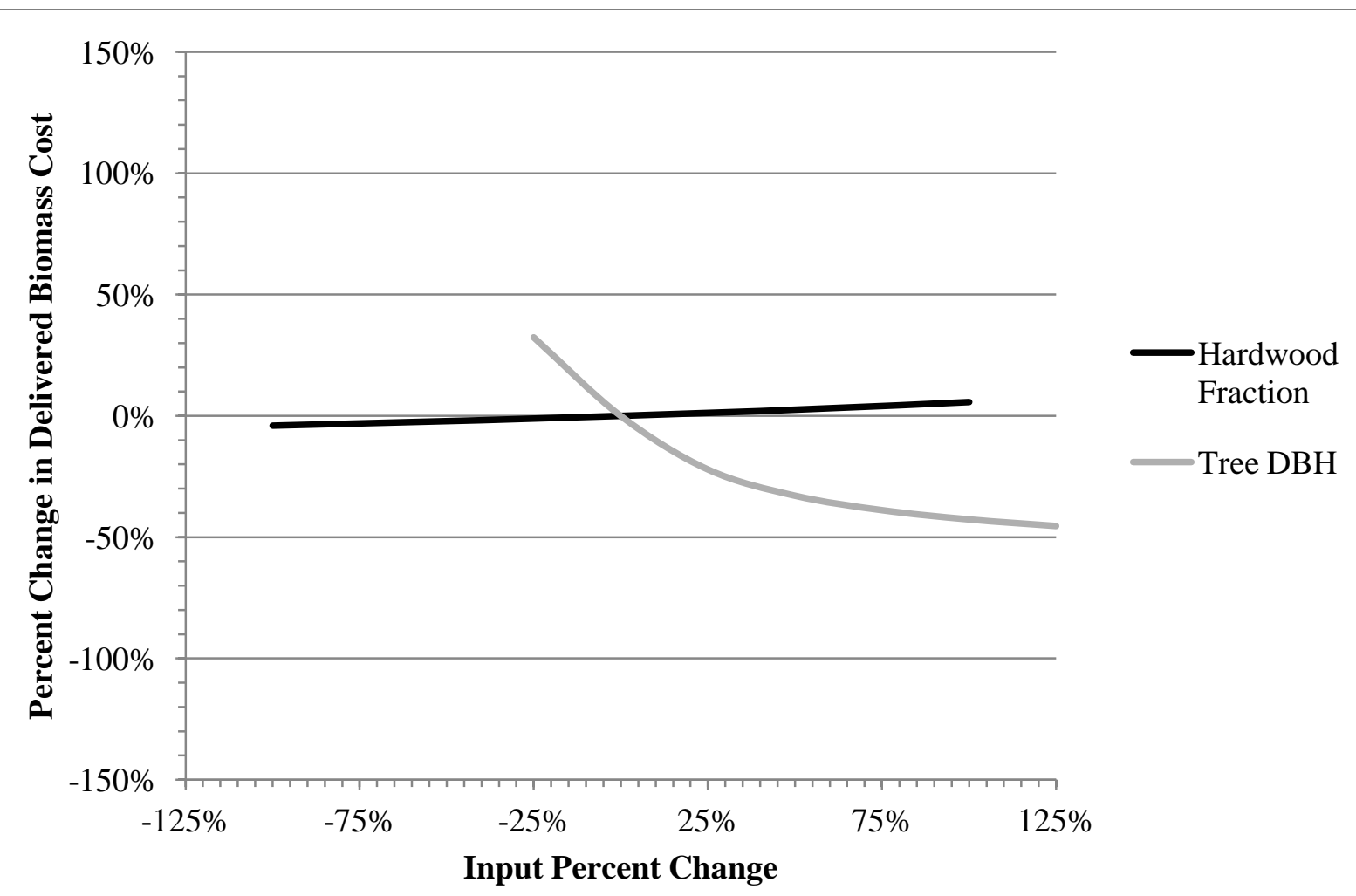

$*$ The baseline delivered biomass cost $(0,0)$ is $\$ 30$ per GT. 
Figure 3.7

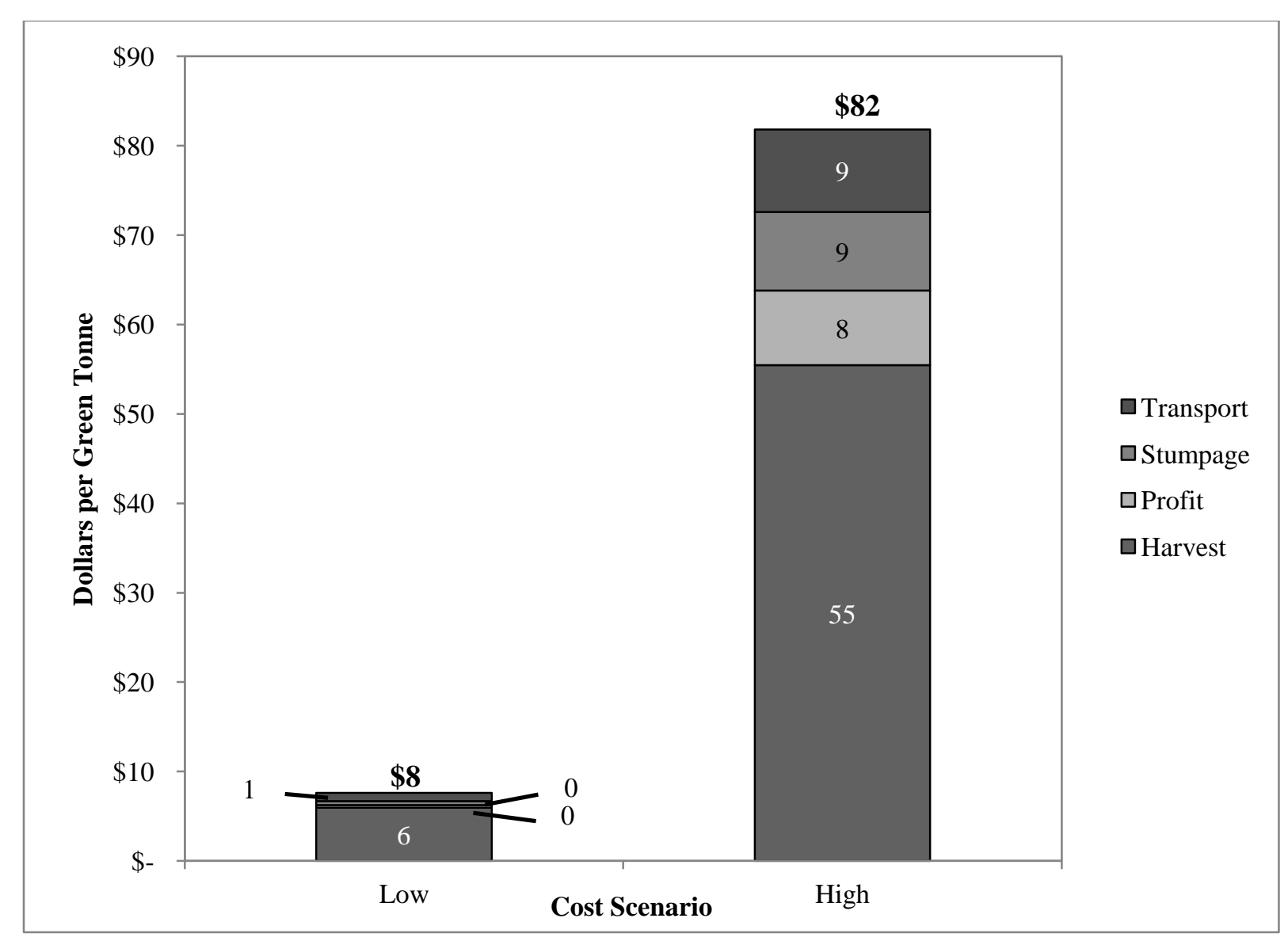




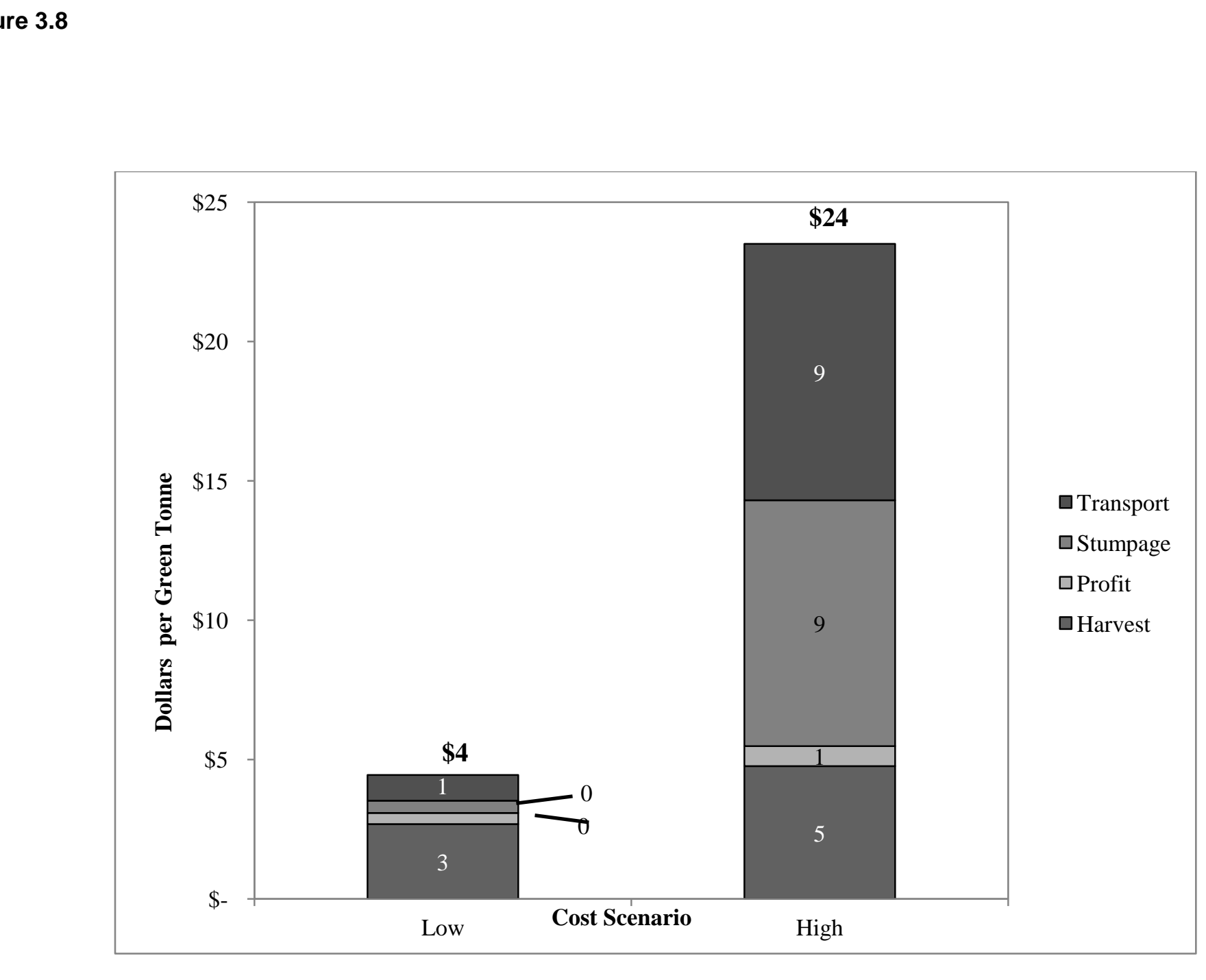

Figure 3.8

(1)

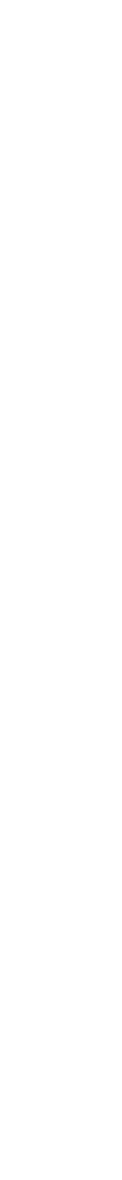

\section{Figure 3.8}
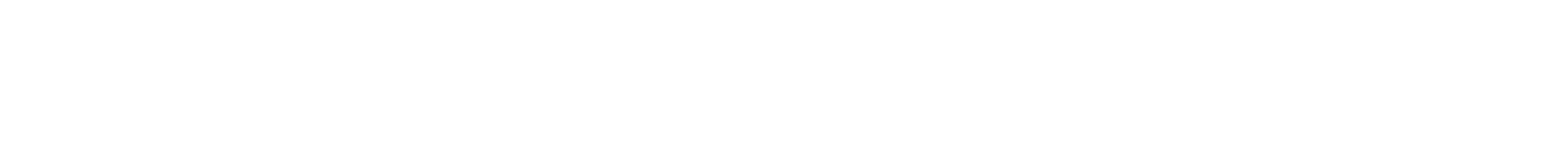